Marine Environmental Research

March 2017, Volume 124, Pages 54.60

http://dx.doi.org/10.1016/i.marenvres.2016.01.001

http://archimer.ifremer.fr/doc/00309/42064/

(c) 2016 Elsevier Ltd. All rights reserved.

\title{
DNA damage in dab (Limanda limanda) and haddock (Melanogrammus aeglefinus) from European seas
}

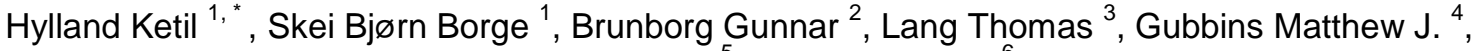 \\ Le Goff Jérémie ${ }^{5}$, Burgeot Thierry ${ }^{6}$
}

${ }^{1}$ Department of Biosciences, University of Oslo, PO Box 1066, Blindern, 0316 Oslo, Norway

${ }^{2}$ National Institute of Public Health, PO Box 4404 Nydalen, 0403 Oslo, Norway

3 Thünen Institute of Fisheries Ecology, Deichstr. 12, 27472 Cuxhaven, Germany

${ }^{4}$ Marine Scotland Science, Marine Laboratory, 375 Victoria Road, Aberdeen, AB11 9DB, UK

${ }^{5}$ Adn'Tox, GRECAN, Centre François Baclesse, Avenue du Général Harris, 14076 Caen Cedex 05,

France

${ }^{6}$ IFREMER, Laboratory of Ecotoxicology, Rue de I'lle d'Yeu. B.P. 21105, 44311 Nantes Cédex 03,

France

* Corresponding author : Ketil Hylland, email address : ketilhy@ibv.uio.no

\begin{abstract}
:
Dab (Limanda limanda) and haddock (Melanogrammus aeglefinus) were collected from coastal and offshore locations in the Baltic (dab only), North Sea (haddock from one location only) and Iceland. Blood was analysed for DNA strand breaks using the comet assay and liver samples for DNA adduct concentrations. DNA strand breaks were at background levels in dab from the two Iceland locations and from the Dogger Bank. The highest levels were observed in dab from the Firth of Forth, Ekofisk and the German Bight. Hepatic DNA adducts in dab were highest at Ekofisk, in the Baltic and Dogger Bank, below detection limit in dab from Iceland and low in dab from the Firth of Forth and German Bight. There was large variation in DNA strand breaks between locations and individuals for haddock, particularly from Iceland. Adduct concentrations were elevated in haddock from both Iceland and the Firth of Forth. A general linear model (GLM) suggested that, in addition to location, the size of dab and its general condition contributed to explaining the observed variability in DNA strand breaks. A GLM for adducts in dab similarly allocated most of the variability to location, but with a possible contribution from CYP1A activity. There were no apparent differences between male and female dab for any of the methods. There was no obvious relationship between strand breaks and adducts in the same fish although dab from Ekofisk and Iceland had respectively high and low responses using both methods. The results from this large-scale study showed pollution-related genotoxicity for dab, that fish blood samples can be conserved prior to comet analyses and that there are clear species differences in genotoxic responses even when collected at the same location.
\end{abstract}




\section{Highlights}

- A method was established for employing the comet assay in large-scale field studies. Genotoxic responses in dab were low in the reference locations and high in polluted locations. There were major species differences in the genotoxic responses of dab and haddock collected from the same locations. There was no direct correspondence between DNA strand breaks in red blood cells and hepatic DNA adducts.

Keywords : ICON, Comet, DNA adducts, Genotoxicity, Haddock, Dab, European seas 


\section{Introduction}

The aquatic environment is the ultimate repository for a major proportion of anthropogenic waste, with a wide range of different chemicals being continuously introduced to coastal and offshore marine areas from rivers, atmospheric inputs as well as coastal and offshore point sources. While most of the chemicals released to the environment have low biological activity and are quickly degraded, some cause toxicity in marine organisms through e.g. interactions with ion regulation (Bjerregaard and Vislie, 1985), hormonal regulation (Kime, 1995), immune functions (Reynaud and Deschaux, 2006), the nervous system (Bocquene et al., 1990), by reducing the integrity of membranes (Broeg et al., this volume) or modifying nucleic acids (Brinkmann et al., 2014). Interaction of chemicals with nucleic acids, potentially resulting in genotoxicity, has been identified as one of the most important mechanism of action since damage to DNA can ultimately cause cell death, carcinogenesis and mutations, hence potentially affecting both individual health and the next generation through germ-line defects (Anderson et al., 1994; Rinner et al., 2011). Nucleic acids, including DNA, may be damaged through many mechanisms, some of which will be promoted through the presence of specific chemicals. Such mechanisms include strand breaks or base modifications, caused by reactive molecules, intercalation of substances between double-stranded DNA strands, potentially causing reading and copying errors, and covalent binding of chemicals to bases or sugars. DNA strand breaks have been most widely quantified through single-cell electrophoresis (Singh et al., 1988), a method that has been found its applications in both vertebrate (Collins and Gaivão, 2007; Collins et al., 1997) and invertebrate (Lewis and Galloway, 2008; Mamaca et al., 2005) systems. Covalent binding of chemicals to DNA has generally been quantified through ${ }^{32} \mathrm{P}$ postlabelling, a method similarly used in both human toxicology (Balbo et al., 2014) and ecotoxicology (Cachot et al., 2013; Ericson et al., 1998; Reichert and French, 1994). In addition to direct damage to the DNA thread, chromosomal damage has been widely investigated, most commonly as micronucleus formation (e.g. Lorge et al., 2008).

A potential for different chemicals to cause DNA damage in marine fish species has been amply documented in many laboratory studies. Increased DNA strand breaks, as documented using the comet assay, has been used with a range of fish species, but predominantly freshwater species (reviewed in Frenzilli et al., 2009). There is a scarcity of studies in which comet has been used in marine field studies, but some have been performed, e.g. using dab, Akcha et al., (2004, 2003) or butterfish (Bombail et al., 2001). One reason for the lack of studies is the challenge of keeping cells viable until analysis. Protocols have been developed to maintain fish blood cells for up to $48 \mathrm{hrs}$ (Ramsdorf et al., 2009), but this is not sufficient for most field surveys where samples may have to be kept for weeks prior to analysis. In contrast to comet, DNA adducts have been used extensively in marine field-based studies (Aas et al., 2003; Ericson et al., 1998; Reichert and French, 1994; Rose et al., 2000) and was as early as in the 1990ies recommended for use in national and international monitoring programmes

(OSPAR, 1998). 
Any chemical that has a potential to be reactive or increase cellular oxidative stress may cause increased damage to DNA, as will chemicals that can intercalate between strands or bind to the molecule. There has been a particular focus on polycyclic aromatic hydrocarbons (PAHs) in this context, but a swathe of other environmental contaminants may also cause genotoxicity in marine organisms, including dichlorobenzene (Ganesan et al., 2013), natural toxins (Cavas and Konen, 2008) and styrene (Mamaca et al., 2005).

The current study is part of an international project, $\operatorname{ICON}^{1}$ (see Hylland et al., this volume), in which fish, other marine organisms and sediments were investigated at a range of coastal and offshore locations in the Mediterranean. Seine estuary, Wadden Sea, North Sea, Baltic and Iceland. Previous studies have suggested that the entire North Sea may be contaminated by PAHs (Hylland et al., 2006). Concentrations of PCBs and PAHs in areas around Iceland are the lowest reported for any oceanographic region in the North Atlantic (Schulz-Bull et al. 1998) and Iceland was hence selected as a reference area for ICON.

Two fish species were included in the current study: dab (Limanda limanda) and haddock (Melanogrammus aeglefinus). Dab is a benthic flatfish that will be chronically exposed to environmental contaminants through feeding and direct contact with contaminated sediments. Primary food sources are benthic invertebrates such as crustaceans and polychaetes, but molluscs, small echinoderms and fish are also part of the diet (Braber and de Groot 1973). Dab is mainly found in shallow waters (less than $100 \mathrm{~m}$ depth) from the Bay of Biscay northwards, including the southern part of the Baltic.. The species has been used extensively in monitoring programmes in the southern North Sea (Dethlefsen et al. 2000), has been target species in international research workshops (Bayne et al., 1988; Stebbing et al., 1991) and has been recommended by $\mathrm{ICES}^{2}$ as a monitoring species. Haddock is a gadoid, but has a demersal life-style not that different to that of the two flatfish species above.

Haddock mainly feed on sediment-dwelling species and benthic fish eggs. It is common throughout the northern North Sea and northwards, but not found in the southern North Sea, the Baltic or south of the English Channel. Haddock has become a target species in the Norwegian monitoring programme around oil and gas platforms, partly due to its apparent sensitivity to genotoxic contaminants (Balk et al., 2011; Hylland et al., 2006). Surveys off the Norwegian coast as part of the monitoring programme for environmental impacts of offshore oil and gas production have reported increased concentrations of hepatic DNA adducts in haddock collected in areas with high offshore activity, but this was not evident for Atlantic cod (Gadus morhua) or saithe (Pollachius virens) (Grøsvik et al., 2010).

The aim of the current study was to quantify DNA damage in two fish species from coastal and offshore areas in the Northeast Atlantic with varying inputs of contaminants. The study also aimed to compare the results from two methods to determine genotoxicity, the comet assay and DNA adduct concentration, as well as compare the sensitivity of the two investigated fish species to genotoxic

${ }^{1}$ ICON: international workshop on marine integrated contaminant monitoring

2 ICES: International Council for Exploration of the Seas; http://www.ices.dk 
contaminants in their habitat. Finally, the study aimed to identify non-contaminant factors that affect levels of DNA damage. 


\section{Materials and methods}

\section{Locations}

All fish were collected by means of bottom trawling during a research cruise with RV Walther Herwig III in August/September 2008. For the purposes of this study, fish were sampled at five locations in the North Sea: Firth of Forth, Ekofisk, German Bight and Dogger Bank, as well as in the Baltic and at locations southeast and southwest of Iceland (cf Hylland et al., this volume; Tables 1 and 2). The Firth of Forth $(\mathrm{FoF})$ is an area influenced by inputs from industrial activities as well as maritime activities (Elliott and Griffiths 1987). The German Bight (GB) is another area of extensive maritime activities as well as receiving inputs from the two rivers Elbe and Weser (Ruus et al., 2006). The Dogger Bank (DB) is a feeding and spawning area for commercial fish in the North-East Atlantic, including dab (Heessen and Rijnsdorp 1989). Ekofisk (EF) is in an area with high density of oil and gas platforms (Brooks et al., 2011). The location in the Baltic is the Mecklenburg bight. Two locations in Iceland were used for reference: Iceland southeast (ISE), located just south of the glacier Vatnajökull, and Iceland southwest (ISW) in the open ocean west of Reykjavik were both designated as reference areas. After trawling, fish were kept alive by rapid transfer to large tanks with pre-cooled, flow-through seawater. Further processing took place within $1 \mathrm{~h}$.

\section{Sampling}

Fish were terminated prior to sampling. Blood was extracted from the caudal vein into heparin precoated syringes and immediately diluted 1:400 (by volume) using PBS-EDTA $\left(\mathrm{KH}_{2} \mathrm{PO}_{4} 0.200 \mathrm{~g} \mathrm{~L}^{-1}\right.$; $\mathrm{KCl}, 0.200 \mathrm{~g} \mathrm{~L}^{-1} ; \mathrm{Na}_{2} \mathrm{HPO}_{4} 12 \mathrm{H}_{2} \mathrm{O}, 2.902 \mathrm{~g} \mathrm{~L}^{-1}$; NaCl, $8.000 \mathrm{~g} \mathrm{~L}^{-1}$; EDTA, $3.72 \mathrm{~g} \mathrm{~L}^{-1}$; $\left.\mathrm{pH} 7.4\right)$ and subsequently kept on ice until further processing. Liver and gonad weights were recorded, and otoliths collected for subsequent age determination. Bile was extracted and liver, gonad and muscle samples were collected from the same individuals and snap-frozen in liquid nitrogen. Tissue samples not used in this study were distributed to other laboratories within the ICON consortium.

\section{Comet assay}

Each sample of diluted blood (see above) was diluted 1:10 (by volume) with low melting point agarose (0.0075 $\mathrm{g} \mathrm{NuSieve}{ }^{\circledR}$ GTG ${ }^{\circledR}$ Agarose $\mathrm{g} \mathrm{mL}^{-1}$ buffered salt solution; $37^{\circ} \mathrm{C}$ ) and deposited on Gelbond ${ }^{\circledR}$ films (Gutzkow et al. 2013). The films were marked in line with pre-designed templates and kept in refrigerated lysis buffer $(2.5 \mathrm{M} \mathrm{NaCl}, 0.1 \mathrm{M}$ EDTA, $10 \mathrm{mM}$ Tris, $1 \%$ sodium lauryl sarcosinate, to which $1 \mathrm{~mL}$ of Triton X-100 and $10 \mathrm{~mL}$ of DMSO per $100 \mathrm{~mL}$ solution had been added the same day; final $\mathrm{pH}$ 10) for a period ranging from 10-26 days. The comet assay protocol was based on Singh et al. (1988), with modifications as described in Gutzkow et al. (2013).

An Olympus BX51 microscope with light source (Olympus Burner, Japan; Osram Mercury Short-Arc HBO® 100 W/2 lamp, Germany) and A312f camera (Basler Vision Technologies, Germany) were used with the 'Comet assay IV' software (Perceptive Instruments, UK) for image analysis. Visualization of the nucleoids was achieved using the SYBR® Gold dye which results in emission of fluorescence as 
a result of DNA binding. Nucleoid density and background was considered in line with standards for the comet assay and gels with high nucleoid density and/or high background were not analysed. Comets were quantified in fifty cells for each individual. In a procedure where the operator has to select the nucleoids for analysis, a set of guidelines were followed to prevent bias; there was no selection of nucleoids in close vicinity of each other (overlapping or potentially overlapping if they had been damaged), nucleoids close to the edge of the image (not possible to recognize potential overlapping with nucleoids outside the image), abnormal nucleoids (e.g. abnormal shape of nucleoid, tail in wrong direction, etc.) and nucleoids close to foreign objects. The software performed calculations of tail intensity (\% tail DNA) for each nucleoid (comet). The scoring was performed with no knowledge as to the origin of the samples and as far as possible without manual interference, however, obvious errors with respect to marking of the comets was corrected when this could be done visually.

\section{Adduct analyses}

The procedure was as described in Le Goff et al. (2006). Two to four livers from fish with similar characteristics (location, size, sex) were pooled for each analysis. For fish of each pool, the amounts of liver were taken homogeneously in order to obtain samples of approximately 80-100 mg of final tissue. The distribution of samples between pools can be found in the supplementary material. For each pool, purified DNA was obtained by liquid-liquid extraction with phenol/chloroform, after homogenisation of liver, isolation of cell nuclei using a sucrose gradient and treatment with RNases A and T1.

For each extracted sample, the DNA concentration in solution was quantified by its absorbance at 260 nm. The absorbance ratios A260/A280 and A260/A230 associated with the absorbance profile of samples between $230 \mathrm{~nm}$ and $300 \mathrm{~nm}$ were used to verify the quality of DNA solutions (more especially the absence of contamination by RNA and/or proteins). The protocol for adduct analyses is suitable for quantification of so-called "bulky" DNA adducts. In order to express the results, labelled DNA adducts were compared to the labelling of a known quantity of nucleotides. Results were expressed in Relative Adducts Levels (RAL) for $10^{8}$ non-labelled nucleotides.

\section{Statistics}

Differences in \% tail intensity (DNA strand breaks) and hepatic adduct concentrations in dab and haddock between locations were tested using non-parametric Kruskal-Wallis and subsequent comparisons of means using Dunn's posthoc test (Zar 2010). Both comet (\% tail intensity, logtransformed) and DNA adducts (concentrations) were subjected to multiple regression analyses (generalised linear models, GLM) with forward selection of the factors location, age, weight, LSI, GSI, CYP1A activity (EROD). A probability of $\mathrm{P}<0.05$ was considered significant for all statistical analyses. Values below (for adducts) were set to half the detection limit. 


\section{Results}

The comet analyses reported here were performed on erythrocytes from dab collected at six locations: Iceland SE (ISE), Iceland SW (ISW), Firth of Forth (FoF), Ekofisk (EF), Dogger Bank (DB) and the German Bight (GB), and for haddock at the three locations where it could be found: ISE, ISW and FoF. The median tail intensity for dab erythrocytes was around $2 \%$ at the two Iceland locations and DB, which is presumably close to the baseline level (Figure 1A). There were however some individuals at ISE with high damage. Dab collected at FoF all had elevated percentage of strand breaks with a median tail intensity around $30 \%$, whereas dab from both EF and GB had median tail intensities around 10\% with what appeared to be a bimodal distribution (Figure 1A). There was significantly more DNA damage in erythrocytes from dab collected at FoF and EF compared to dab collected at the Iceland locations (Dunn's test; $\mathrm{p}<0.001$ ). Median tail intensities were however in what would be expected to be background range in erythrocytes from dab collected at the other two locations, ISW and DB, i.e. below 10\%. The best generalised linear model for DNA strand breaks in dab erythrocytes included $64 \%$ of the total variability ( $\mathrm{p}<0.0001)$ and included weight and LSI in addition to location (p-values of 0.002, 0.0001 and $<0.0001$, respectively). There was high level of DNA strand breaks in haddock samples from ISE with median tail intensity close to 50\%, but lower levels in dab collected at ISW and FoF (Figure 1B). There was very high variability in tail intensity at all three locations.

Hepatic DNA adducts were analysed in dab from ISW, FoF, EF, DB, GB and the Baltic, for haddock at ISE and FoF. In concordance with results for comet, all dab samples from Iceland were below the detection limit $\left(0.2 \mathrm{RAL} \times 10^{8}\right)$ and samples from EF had the highest median concentration of adducts (Figure 2A). In contrast with comet, however, there were low median adduct concentrations in haddock sampled at FoF and GB, whereas adduct concentrations were elevated in dab from DB. Dab from the Baltic had median adduct concentration similar to adduct concentrations in dab from DB. Each analysis represented a pool of three individuals and the high variability for samples from FoF and GB was suprising. A non-parametric statistical analysis was performed, bearing in mind that some values had to be set to half the detection limit, which indicated that there could be significant differences in the material (Kruskal-Wallis, $\mathrm{p}=0.004$ ). Dunn's posthoc analysis showed that hepatic adduct concentrations in haddock from $\mathrm{EF}$ and $\mathrm{DB}$, but not BA, were significantly different from adduct concentrations in haddock from ISE. Median hepatic adduct concentrations in haddock from Iceland were similar to median adduct concentrations in haddock from FoF (Figure 2B). It is notable that one of six samples from Iceland was below the detection limit $\left(0.02\right.$ RAL x $\left.10^{8}\right)$ whereas the others ranged from 0.5 to 3 RAL $\times 10^{6}$. A GLM was calculated which could account for $62 \%$ of the total variability, with location as the only significant explanatory variable (total model $\mathrm{p}<0.0001$, location $\mathrm{p}<0.0001$ ). The only other variable that was bordeline was CYP1A activity (EROD), which had a p-value of 0.06. 


\section{Discussion}

The results reported herein clearly show that the comet method can be used in field studies, through storage of embedded cells in lysis buffer for up to three weeks. Although the comet assay has been used in field studies previously e.g. Akcha et al. (2004, 2003), this is the first large-scale study in which the method has been used to quantify genotoxic impacts in natural fish populations. As has been highlighted in other studies, e.g. on DNA adducts (Aas et al., 2003), it is important to have established what is a natural background for any contaminant-related response, and it was necessary to look outside the North Sea to find conditions with close to natural background for genotoxic contaminants. .

The results for comet in dab clearly indicated that waters around Iceland provide a good reference area, but the results also suggest that dab at offshore locations, i.e. Dogger Bank, are not strongly affected by conditions that give rise to DNA strand breaks. The other three locations, all coastal, all had higher relative proportion of individuals with more strand breaks, although only dab from the Firth of Forth and Ekofisk had significantly more damage than dab from Iceland. The overall results for DNA strand breaks in dab red blood cells fit with expectations in that fish from coastal areas (Firth of Forth, German Bight) and areas with local sources (Ekofisk) have higher levels of damage than fish from reference areas (Iceland) and offshore areas with no known local sources (Dogger Bank).There was no clear link between the level of DNA strand breaks in dab with oxidative stress markers (Carney Almroth et al., this volume) or concentrations of PAH-metabolites in bile (cf Kamman et al., this volume). Pyrene metabolites in bile would indicate recent exposure to PAHs and was low in dab from Iceland and Dogger Bank, but also low in dab from Firth of Forth and Ekofisk. The highest PAH exposure appeared to be in the inner stations of the German Bight and the Baltic (Kammann et al., this volume). This is in contrast with results by e.g. Wessel et al. (2010) and Hylland et al. (2006), in which relationships between PAH bile metabolites and DNA damage were reported. The generalised linear model suggested that the size of the fish, but also condition (as liver-somatic index) contributed to explaining some of the variability in DNA strand breaks. By far the most important component in the GLM analyses were locations, however, presumably reflecting general contamination status. Interestingly, there were no apparent differences between male and female dab.

Haddock was not present at all locations and was only sampled at the two Icelandic sites and off the Firth of Forth. Contrary to the results for dab, the highest median level of DNA strand breaks was found for dab from SE Iceland and the lowest from the most polluted area, i.e. the Firth of Forth. The variability within each location was however very large. With the data from this study it is not possible to find out whether the large variability between individual haddock in DNA strand breaks was due to methodological issues or whether this is natural variability in a haddock population. The samples were taken at the same time as samples for dab and treated identically, so the results could suggest that separate protocols need to be developed for each fish species. 
As for the comet data, hepatic DNA adduct concentrations in dab were lowest at the Iceland location, but were also low in dab from the Firth of Forth. Somewhat surprisingly there were individuals/pools with values below the detection limit from both the Firth of Forth and the German Bight, two areas that have been shown to be highly contaminated earlier (OSPAR, 2010), but possibly less so during the ICON campaign (Robinson et al., this volume). No clear link could however be observed between DNA strand breaks or DNA adduct and concentrations of hepatic PCBs in either dab or haddock. Phase-I biotransformation (cytochrome P4501A) activity was clearly induced in dab collected at Ekofisk (Carney Almroth et al, this volume), corresponding with high level of DNA strand breaks and the highest median and single DNA adduct concentrations. PAH-metabolite analyses did not indicate high PAH exposure at that site (Kammann et al., this volume), however, but it is known that a large proportion of PAHs in the effluent from production wells is alkylated, hence would not be detected in this chemical analysis. This effluent is complex and has earlier been shown to be toxicologically active in the waters surrounding the Ekofisk platform area (Brooks et al., 2011).

Barsiene et al. (2013) quantified micronuclei and related endpoints in blood samples from the same dab as analysed herein. In accordance with the results observed for strand breaks and hepatic adducts, they found low levels of aberrations in erythrocytes from dab from Iceland. The highest frequencies of erythrocyte chromosomal aberrations were however found in dab collected in the German Bight and at Dogger Bank, with intermediate levels for dab collected at Ekofisk and the Firth of Forth. The three different measures of genotoxicity do therefore not appear to reflect the same processes, but all three would appear to be linked to contaminant stress since responses in dab from the Iceland locations were low for all three. The three methods reflect different temporal processes, with strand breaks being an acute response, micronucleus formation intermediate and hepatic DNA adducts the most conservative. A clear time dependency would however be disrupted by endogenous processes and mobilisation of accumulated contaminants. There is therefore a need for more knowledge of which contaminants affect specific genotoxic responses, as well as any involvement of endogenous processes and a time-course of effects.

There were some indications in the data from ICON that species with high concentrations of PAHmetabolites (Kammann et al., this volume) may have low concentrations of hepatic adducts and viceversa. Flounder had comparatively high concentrations of metabolites and low adduct concentrations (data not shown), whereas haddock had low concentrations of metabolites (at the locations where it was sampled, i.e. Iceland and Firth of Forth) and high concentrations of adducts. This could be due to differences in biotransformation patterns between the two species, i.e. that flounder has higher phase-II activity than haddock, hence rapidly shunting any reactive epoxides to metabolites in the bile rather than reactive species in the liver. Similar situations have been described previously, i.e. where two species found in the same habitat express what appear to be very different sensitivities to environmental genotoxicants, most commonly expressed as increased tumour prevalence. Such different sensitivities have earlier been observed for different flatfish species in Puget sound (Johnson et al., 1998) and for two related American freshwater fish species, channel catfish and brown bullhead 
(Hasspieler et al., 1994a, 1994b). There is clearly scope for more detailed studies of biotransformation components and their capacity in different marine fish species in order to understand why some species may be more sensitive to environmental genotoxicants than other. For dab, both PAH-metabolite concentrations and DNA adduct concentrations appear to reflect environmental PAH exposure (Kamman et al., this volume; Robinson et al., this volume).

\section{Conclusions}

A technique was established for using the comet assay in large-scale field studies.

The results show large species differences in genotoxic responses in dab and haddock sampled in the same habitats, possibly associated with differences in biotransformation capacity.

There was no direct correspondence between DNA strand breaks and DNA adducts in the investigated dab populations, although both responses were low in dab from Iceland and high in dab collected in an area with high oil production.

There were no direct relationships between contaminant concentrations in sediment or biota and genotoxic responses in the fish, highlighting the need for both chemical analyses and biological responses in an assessment of contaminants. 


\section{Acknowledgements}

The authors wish to acknowledge the work by colleagues in ICES and OSPAR working groups, i.e. WGBEC, WKIMON, SGIMC, as well as cruise participants and the crew of R/V Walther Herwig III. The French participation was funded by IFREMER and ONEMA. 


\section{Literature references}

Aas, E., Liewenborg, B., Einar Grøsvik, B., Camus, L., Jonsson, G., Fredrik Børseth, J., Balk, L., 2003. DNA adduct levels in fish from pristine areas are not detectable or low when analysed using the nuclease P1 version of the 32P-postlabelling technique. Biomarkers 8, 445-460.

Akcha, F., Hubert, F.V., Pfhol-Leszkowicz, A., 2003. Potential value of the comet assay and DNA adduct measurement in dab (Limanda limanda) for assessment of in situ exposure to genotoxic compounds. Mutat. Res. Toxicol. Environ. Mutagen. 534, 21-32.

Akcha, F., Leday, G., Pfohl-Leszkowicz, A., 2004. Measurement of DNA adducts and strand breaks in dab (Limanda limanda) collected in the field: effects of biotic (age, sex) and abiotic (sampling site and period) factors on the extent of DNA damage. Mutat. Res. Mol. Mech. Mutagen. 552, 197-207.

Anderson, S., Sadinski, W., Shugart, L., Brussard, P., Depledge, M., Ford, T., Hose, J., Stegeman, J., Suk, W., Wirgin, I., others, 1994. Genetic and molecular ecotoxicology: a research framework. Environ. Health Perspect. 102, 3-8.

Balbo, S., Turesky, R.J., Villalta, P.W., 2014. DNA Adductomics. Chem. Res. Toxicol. 27, 356-366.

Balk, L., Hylland, K., Hansson, T., Berntssen, M.H., Beyer, J., Jonsson, G., Melbye, A., Grung, M., Torstensen, B.E., Borseth, J.F., others, 2011. Biomarkers in natural fish populations indicate adverse biological effects of offshore oil production. PlosOne 6, e19735.

Baršienė, J., Rybakovas, A., Lang, T., Andreikėnaite, L., Michailovas, A., 2013. Environmental genotoxicity and cytotoxicity levels in fish from the North Sea offshore region and Atlantic coastal waters. Mar. Pollut. Bull. 68, 106-116.

Bayne, B.L., Addison, R.F., Capuzzo, J.M., Clarke, K.R., Gray, J.S., Moore, M.N., Warwick, R.M., 1988. An overview of the GEEP workshop. Mar. Ecol. Prog. Ser., 46, 235-243.

Bjerregaard, P., Vislie, T., 1985. Effects of mercury on ion and osmo-regulation in the shore crab, Carcinus maenas. Comp. Biochem. Physiol. 82C, 227-230.

Bocquene, G., Galgani, F., Truquet, P., 1990. Characterization and assay conditions for use of AChE activity from several marine species in pollution monitoring. Mar. Environ. Res. 30, 75-89.

Bombail, V., Aw, D., Gordon, E., Batty, J. 2001. Application of the comet and micronucleus assays to butterfish (Pholis gunnellus) erythrocytes from the Firth of Forth, Scotland. Chemosphere 44, 383-392.

Braber, L. and de Groot, S. J., 1973. The food of five flatfish species (Pleuronectiformes) in the southern north sea. Neth. J. Sea Res. 6, 163-172.

Brinkmann, M., Blenkle, H., Salowsky, H., Bluhm, K., Schiwy, S., Tiehm, A., Hollert, H., 2014. Genotoxicity of Heterocyclic PAHs in the Micronucleus Assay with the Fish Liver Cell Line RTL-W1. Plos One 9, e85692.

Broeg, K., Kammann, U., Hoeher, N., Lang, T. Lysosomal membrane stability in the liver of dab (Limanda limanda) - Applicability and reliability of assessment criteria under concrete contaminant-related monitoring conditions of coastal-, estuarine-, and offshore locations. (this volume)

Brooks, S.J., Harman, C., Grung, M., Farmen, E., Ruus, A., Vingen, S., Godal, B.F., Baršienė, J., Andreikènaitè, L., Skarphéðinsdóttir, H., Liewenborg, B., Sundt, R.C., 2011. Water Column Monitoring of the Biological Effects of Produced Water from the Ekofisk Offshore Oil Installation from 2006 to 2009. J. Toxicol. Environ. Health A 74, 582-604.

Cachot, J., Cherel, Y., Larcher, T., Pfohl-Leszkowicz, A., Laroche, J., Quiniou, L., Morin, J., Schmitz, J., Burgeot, T., Pottier, D., 2013. Histopathological lesions and DNA adducts in the liver of European flounder (Platichthys flesus) collected in the Seine estuary versus two reference estuarine systems on the French Atlantic coast. Environ. Sci. Pollut. Res. 20, 723-737.

Carney Almroth, B, Hultman, M, Wassmur, B, Sturve, J. Is oxidative stress evident in dab (Limanda limanda) in the North Sea? (this volume)

Cavas, T., Konen, S., 2008. In vivo genotoxicity testing of the amnesic shellfish poison (domoic acid) in piscine erythrocytes using the micronucleus test and the comet assay. Aquat. Toxicol. 90, 154-159.

Collins, A.R., Dobson, V.L., Dušinská, M., Kennedy, G., Štětina, R., 1997. The comet assay: what can it really tell us? Mutat. Res. Mol. Mech. Mutagen. 375, 183-193.

Collins, A.R., Gaivão, I., 2007. DNA base excision repair as a biomarker in molecular epidemiology studies. Mol. Aspects Med. 28, 307-322. 
Dethlefsen, V., Lang, T., Koves, P., 2000. Regional patterns in prevalence of principal external diseases of dab Limanda limanda in the North Sea and adjacent areas 1992-1997. Dis. Aquat. Org., 42, 119-132.

Elliott, M., Griffiths, A. H. 1987. Contamination and effects of hydrocarbons on the Forth ecosystem, Scotland. Proc Royal Soc Edinburgh 93, 327-342.

Ericson, G., Lindesjöö, E., Balk, L., 1998. DNA adducts and histopathological lesions in perch (Perca fluviatilis) and northern pike (Esox lucius) along a polycyclic aromatic hydrocarbon gradient on the Swedish coastline of the Baltic Sea. Can. J. Fish. Aquat. Sci. 55, 815-824.

Frenzilli, G., Nigro, M., Lyons, B., 2009. The Comet assay for the evaluation of genotoxic impact in aquatic environments. Mutat. Res. 681, 80-92.

Ganesan, N., Sathya, T.N., Arunachalam, K.D., 2013. Genotoxicity Evaluation of 1,2 Dichlorobenzene in the Indian Major Carp, Catla catla L. Using Alkaline Comet Assay. Bull. Environ. Contam. Toxicol. 91, 616-622.

Grøsvik, B.E., Meier, S., Liewenborg, B., Nesje, G., Westrheim, K., Fonn, M., Kjesbu, O.S., Skarphéḥinsdóttir, H., Klungsøyr, J., 2010. PAH and biomarker measurements in fish from condition monitoring in Norwegian waters in 2005 and 2008. ICES CM 2010/F:06, 18 p.

Gutzkow, K.B., Langleite, T.M., Meier, S., Graupner, A., Collins, A.R., Brunborg, G., 2013. Highthroughput comet assay using 96 minigels. Mutagenesis 28, 333-340.

Hasspieler, B.M., Behar, J.V., Carlson, D.B., Watson, D.E., Di Giulio, R.T., 1994a. Susceptibility of channel catfish (Ictalurus punctatus) and brown bullhead (Ameriurus nebulosus) to oxidative stress: a comparative study. Aquat. Toxicol. 28, 53-64.

Hasspieler, B.M., Behar, J.V., Di Giulio, R.T., 1994b. Glutathione-dependent defense in channel catfish (Ictalurus punctatus) and brown bullhead (Ameriurus nebulosus). Ecotoxicol. Environ. Saf. 28, 82-90.

Heessen, H. J. L., Rijnsdorp, A. D. 1989. Investigations on egg production and mortality of cod (Gadus morhua L.) and plaice (Pleuronectes platessa L.) in the southern and eastern North Sea in 1987 and 1988. Early Life Hist Fish 191, 15-20.

Hylland, K., Beyer, J., Berntssen, M., Klungsoyr, J., Lang, T. and Balk, L. 2006. May organic pollutants affect fish populations in the North Sea? J. Toxicol. Environ. Health, Part A 69, 125-138.

Hylland, K., Gubbins, M.J., Robinson, C., Burgeot, T., Martínez-Gómez, C., Lang, T., Svavarsson, J., Thain, J.E., Vethaak' AD. How can we quantify impacts of contaminants in marine ecosystems? The ICON project (this volume)

Johnson, L.L., Landahl, J.T., Kubin, L.A., Horness, B.H., Myers, M.S., Collier, T.K., Stein, J.E., 1998 Assessing the effects of anthropogenic stressors on Puget Sound flatfish populations. J. Sea Res. 39, 125-137.

Kammann, U., Akcha, F., Budzinski, H., Burgeot, T., Gubbins, M.J., Lang, T., Le Menach, K., Vethaak, A.D., Hylland, K. PAH metabolites in fish bile: from the Seine Estuary to Iceland (this volume)

Kime, D.E., 1995. The effects of pollution on reproduction in fish. Rev. Biol. 5, 52-96.

Le Goff J. Gallois J. Pelhuet L. Devier MH. Budzinski H. Pottier D. André V. Cachot J. 2006. DNA adduct measurements in zebra mussels, Dreissena polymorpha. Pallas. Potential use for genotoxicant biomonitoring of fresh water ecosystems. Aquat. Toxicol. 79, 55-64.

Lewis, C., Galloway, T., 2008. Genotoxic damage in polychaetes: A study of species and cell-type sensitivities. Mutat. Res. Toxicol. Environ. Mutagen. 654, 69-75.

Lorge, E., Hayashi, M., Albertini, S., Kirkland, D., 2008. Comparison of different methods for an accurate assessment of cytotoxicity in the in vitro micronucleus test. Mutat. Res. Toxicol. Environ. Mutagen. 655, 1-3.

Mamaca, E., Bechmann, R.K., Torgrimsen, S., Aas, E., Bjørnstad, A., Baussant, T., Floch, S.L., 2005. The neutral red lysosomal retention assay and Comet assay on haemolymph cells from mussels (Mytilus edulis) and fish (Symphodus melops) exposed to styrene. Aquat. Toxicol. 75, 191-201.

OSPAR, 1998. JAMP guidelines for contaminant-specific biological effects monitoring. Oslo and Paris Commissions, $38 \mathrm{p}$.

OSPAR, 2010. Quality Status Report 2010. OSPAR Commission, London, 176 pp.

Ramsdorf, W.A., Guimarães, F. de S.F., Ferraro, M.V.M., Gabardo, J., Trindade, E. da S., Cestari, M.M., 2009. Establishment of experimental conditions for preserving samples of fish blood 
for analysis with both comet assay and flow cytometry. Mutat. Res. Toxicol. Environ. Mutagen. 673, 78-81.

Reichert, W.L., French, B., 1994. The 32P-postlabelling protocols for assaying levels of hydrophobic DNA adducts in fish (No. NMFS-NNFSC-14). US Department of Commerce.

Reynaud, S., Deschaux, P., 2006. The effects of polycyclic aromatic hydrocarbons on the immune system of fish: A review. Aquat. Toxicol. 77, 229-238.

Rinner, B.P., Matson, C.W., Islamzadeh, A., McDonald, T.J., Donnelly, K.C., Bickham, J.W., 2011. Evolutionary toxicology: contaminant-induced genetic mutations in mosquitofish from Sumgayit, Azerbaijan. Ecotoxicology 20, 365-376.

Robinson, C.D., Webster, L., Martínez-Gómez, C., Burgeot, T., Gubbins, M.J., Thain, J.E., Vethaak, A.D., McIntosh, A.D., Hylland, K. Assessment of contaminant concentrations in sediments, fish and mussels sampled from the North Atlantic and European regional seas within the ICON project (this volume)

Rose, W.L., French, B.L., Reichert, W.L., Faisal, M., 2000. DNA adducts in hematopoietic tissues and blood of the mummichog (Fundulus heteroclitus) from a creosote-contaminated site in the Elizabeth River, Virginia. Mar. Environ. Res. 50, 581-589.

Ruus, A, Tollefsen, K-E, Grung, M, Klungsøyr, J, Hylland, K. 2006. Accumulation of contaminants in pelagic organisms, caged blue mussels, caged cod and semi-permeable membrane devices (SPMDs). In: Biological effects of contaminants in pelagic ecosystems. Hylland, K, Vethaak, AD, Lang, T (Eds), SETAC, p 51-75.

Schulz-Bull, D. E., Petrick, G., Bruhn, R., Duinker, J. C. 1998. Chlorobiphenyls (PCB) and PAHs in water masses of the northern North Atlantic. Mar. Chem. 61, 101-114.

Singh, N. P., McCoy, M. T., Tice, R. R., Schneider, E. L. 1988. A simple technique for quantitation of low levels of DNA damage in individual cells. Exp. Cell Res. 175, 184-191.

Stebbing, A.R.D., Dethlefsen, V., Addison, R.F., Carr, M., Chapman, P.M., Cofino, W., Heip, C.H.R., Karbe, L., Moore, M.N., Vethaak., A.D., 1992. Overall summary and some conclusions from the Bremerhaven workshop. Mar. Ecol. Prog. Ser. 91, 1-8.

Wessel, N., Santos, R., Menard, D., Le Menach, K., Buchet, V., Lebayon, N., Loizeau, V., Burgeot, T., Budzinski, H., Akcha, F., 2010. Relationship between PAH biotransformation as measured by biliary metabolites and EROD activity, and genotoxicity in juveniles of sole (Solea solea).

Mar. Environ. Res. 69, S71-S73.

Zar, J. H. 2010. Biostatistical analysis. Upper Saddle River, N.J., Prentice-Hall/Pearson. 
Table 1. Overview of dab (Limanda limanda) sampled and analyses performed.

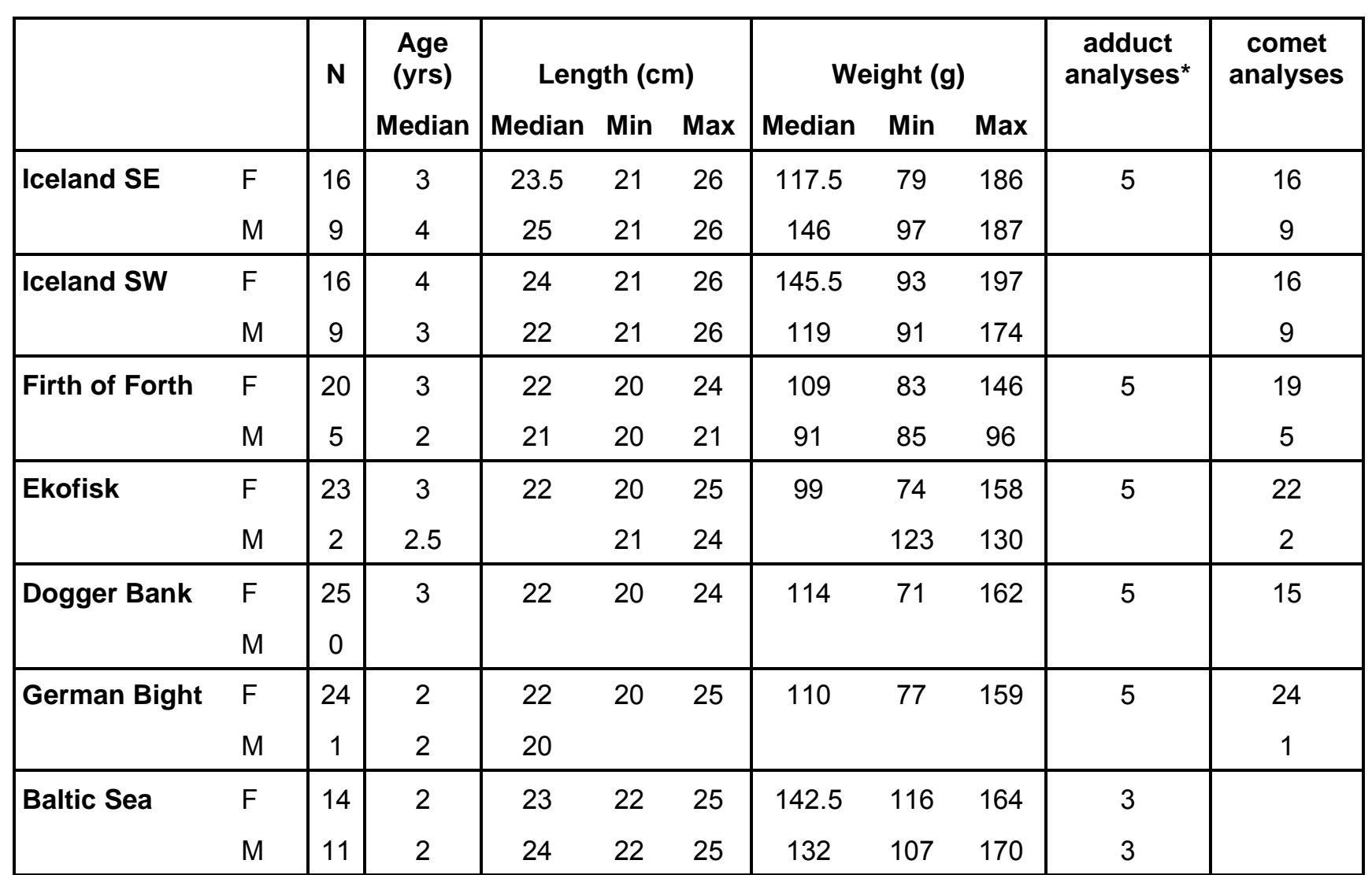

* pooled liver samples (3) 
Table 2. Overview of haddock (Melanogrammus aeglefinus) sampled and analyses performed.

\begin{tabular}{|c|c|c|c|c|c|c|c|c|c|c|c|}
\hline & & \multirow[t]{2}{*}{$\mathbf{N}$} & \multirow{2}{*}{$\begin{array}{c}\text { Age (yrs) } \\
\text { Median }\end{array}$} & \multicolumn{3}{|c|}{ Length $(\mathbf{c m})$} & \multicolumn{3}{|c|}{ Weight (g) } & \multirow[t]{2}{*}{$\begin{array}{c}\text { adduct } \\
\text { analyses* }\end{array}$} & \multirow[t]{2}{*}{$\begin{array}{c}\text { comet } \\
\text { analyses }\end{array}$} \\
\hline & & & & Median & Min & Max & Median & Min & Max & & \\
\hline \multirow[t]{2}{*}{ Iceland SE } & $\mathrm{F}$ & 9 & 3 & 40 & 36 & 42 & 662 & 424 & 798 & 3 & 8 \\
\hline & $M$ & 16 & 3 & 39 & 33 & 45 & 532 & 301 & 876 & 3 & 14 \\
\hline \multirow[t]{2}{*}{ Iceland SW } & $\mathrm{F}$ & 10 & 3 & 36 & 32 & 42 & 479 & 288 & 725 & & 10 \\
\hline & $M$ & 15 & 3 & 37 & 30 & 44 & 491 & 266 & 789 & & 14 \\
\hline \multirow[t]{2}{*}{ Firth of Forth } & $\mathrm{F}$ & 12 & 3 & 32 & 25 & 37 & 284 & 205 & 523 & 5 & 9 \\
\hline & $\mathrm{M}$ & 13 & 3 & 27 & 25 & 31 & 204 & 142 & 309 & & 11 \\
\hline
\end{tabular}

* pooled liver samples (3) 


\section{Figure captions}

Figure 1. Tail intensity (\% tail DNA) for A. dab (Limanda limanda), B. haddock (Melanogrammus aeglefinus); single values and median (line) shown; Firth of Forth and Ekofisk were significantly different from both Iceland locations, $\mathrm{p}<0.01$; Dunn's posthoc test; Kruskal-Wallis $\mathrm{p}<0.0001$.

Figure 2. DNA adduct concentration (RAL x $10^{8}$ ) for A. dab (Limanda limanda), B. haddock (Melanogrammus aeglefinus); single values and median (line) shown; Ekofisk and Dogger Bank was significantly different from Iceland SE, $\mathrm{p}<0.05$; Dunn's posthoc test; Kruskal-Wallis $\mathrm{p}=0.004$; note values below detection limit was set to half that limit $(0.01)$. 
Figure 1
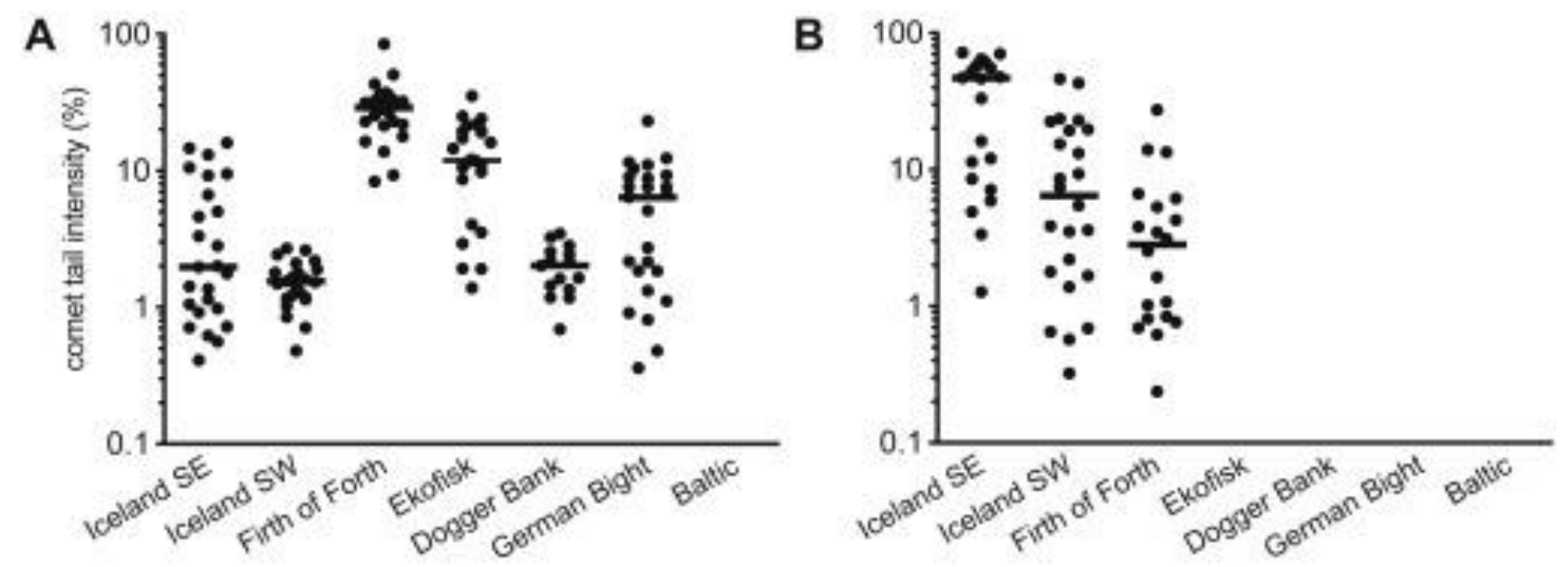

Figure 2
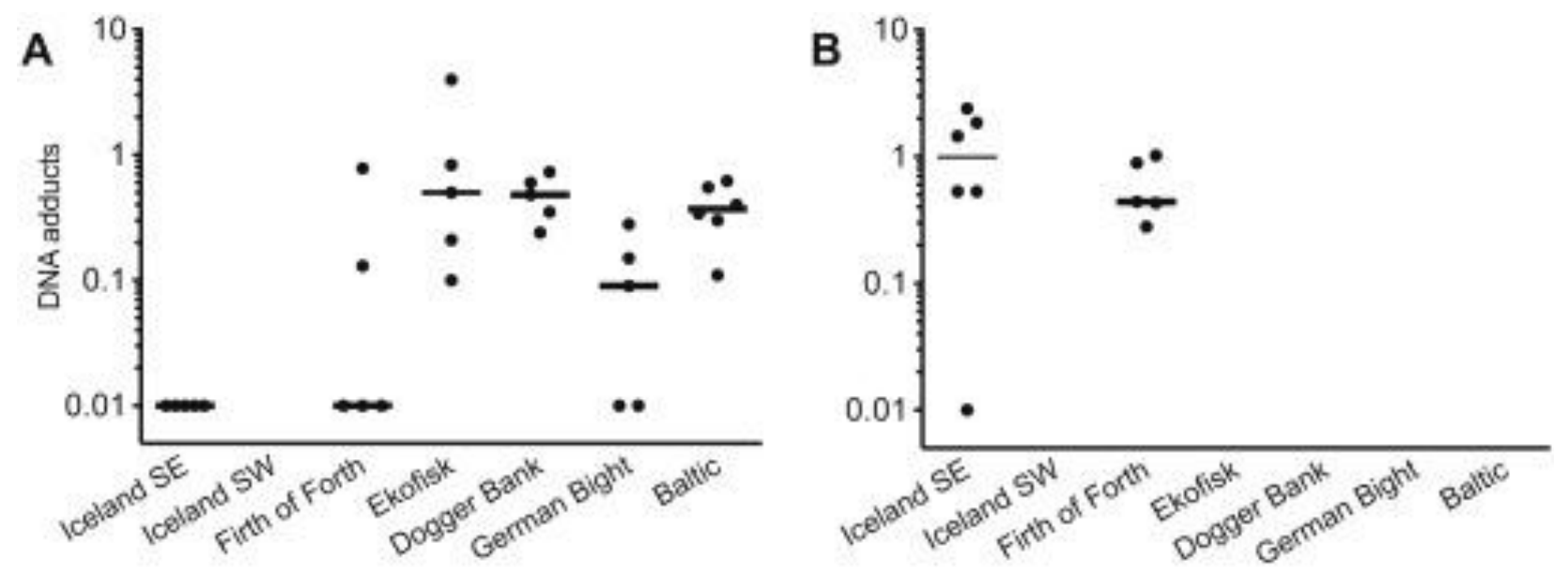